\title{
Sabia usted El "Dragón" se está despertando Parte 2 - Reformas recientes en la educación médica en China
}

\author{
Profesor Andrzej Wojtczak MD., PhD
}

\section{The "Dragon" is awaking Part 2 - Recent reforms in medical education in China}

La educación de los médicos en China se lleva a cabo en las Escuelas o Facultades de Medicina, en las que ingresan los egresados de la enseñanza secundaria. Hay dos tipos de programas: un programa de 3 años que conduce a un certificado y un programa de 5,7 y 8 años que conduce a un título de grado. Entre las 185 Instituciones Médicas, 9 desarrollan un programa de 8 años que acaba con un título de grado (graduado en Medicina), 43 desarrollan un programa de 7 años que conduce a un título de Master en Medicina, 15 desarrollan un programa de 5 años que otorga un título de "Bachelor" en Medicina, y finalmente 20 facultades desarrollan un programa de 3 años que otorga un título de Certificado de Asociado en Medicina. Esta diversidad de programas educativos obedece a diferentes necesidades de tipo nacional, regional y local. El programa de 5 años acabará siendo el tipo más frecuente durante un largo período de tiempo, mientras que se prevé que el programa de 3 años irá desapareciendo.

Desde el año 2000, 63 facultades de medicina, fueron incorporadas a las denominadas "Universidades Comprehensivas". Entre ellas, 10 instituciones médicas de 11, dependían previamente del Ministerio de Salud. Todas ellas actualmente dependen directa o indirectamente del Ministerio de Educación, excepto la Peking Union Medical College (PUMC) que todavía depende del Ministerio de Salud. Sin embargo, el carácter específico de la educación médica y sus necesidades en estas "Universidades Comprehensivas" no son con demasiada frecuencia adecuadamente reconocidas, p.e. la separación de las Facultades de Medicina de los Hospitales docentes. El rápido incremento de los alumnos ingresados, especialmente en las facultades de medicina locales, sin una adecuada dotación de recursos humanos y materiales y hospitalarios, pueden acabar afectando negativamente la
The medical education of doctors in China is carried out in the Medical Colleges or Faculties, which enroll graduates of the high-schools. There are two categories of programs: a certificate-oriented 3-year program, and a degree-oriented 5, 7 and 8 years programs. Among 185 Medical Institutions, 9 runs 8 year program resulting in MD degree, 43 - 7 year program of Master in Medicine, 15 runs 5-year program of Bachelor in Medicine, and 20 a certificate-oriented 3 year program of Associate in Medicine. Diversity of educational programs is focused on different national, regional and local needs. The 5 year program will be a most popular format for a long time, and 3-year one will be disappearing.

Since year 2000, 63 medical schools have been merged into the "Comprehensive Universities" among them 10 of 11 medical institutions that previously reported to the Ministry of Health. All of them now report directly or indirectly to the Ministry of Education, except the Peking Union Medical College (PUMC) which still reports to the Ministry of Health. However, the specific character of medical education and requirements in these "Comprehensive Universities" are too often not adequately recognized i.e. separation of the Medical Colleges from the Teaching Hospitals. The rapid expansion of students' enrollment, especially at local medical schools, without adequate compensation with human and financial resources and hospital facilities, can undermine the quality of education. Time is needed to evaluate the effects of these "mergers" on medical schools. 
calidad educativa. Se requiere tiempo para evaluar los efectos de esta incorporación sobre las facultades de medicina.

La mayoría de las facultades de medicina todavía continúan desarrollando un curriculum tradicional centrado en el profesor, con gran cantidad de clases magistrales masivas y poniendo gran énfasis en la enseñanza y en los exámenes, lo cual lleva a una actitud pasiva de aprendizaje por parte de los estudiantes. Sin embargo, en las últimas dos décadas, en las facultades más avanzadas se han llevado a cabo varias innovaciones curriculares. Estas facultades han hecho esfuerzos para incorporar en sus curricula los principios de la enseñanza integrada, las asignaturas sobre aspectos humanísticos, éticos $\mathrm{y}$ sociales, la informática y el conocimiento del inglés. También han puesto énfasis en el trabajo en pequeños grupos tutorizados, en la adquisición de habilidades para la solución de problemas, en la relación médico-paciente y en la adquisición de actitudes que fomenten el aprendizaje a lo largo de toda la vida. El reto actual tanto para el gobierno como para las Facultades de Medicina es la mejora de la calidad de la educación médica, con el fin de formar personal cualificado que pueda adaptarse a los rápidos cambios de la práctica médica y a las necesidades del pueblo chino.

El Ministerio Chino de Educación se ha comprometido totalmente con el uso de la mejor experteza disponible y los estándares internacionales, provenientes del extranjero, así como con el estímulo de la excelencia académica y de las instituciones educativas. El mejor ejemplo de ellos, ha sido la invitación hecha por el Ministerio de Educación al Instituto para la Educación Médica Internacional (IIME), para llevar a cabo en ocho facultades líderes, la evaluación de las competencias de sus graduados, basadas en el documento de los Requerimientos Globales Mínimos Esenciales (GMER). La evaluación fue seguida por un proceso de definición de estándares internacionales a nivel de los estudiantes y a nivel de facultad. Esto ha permitido preparar un detallado informe sobre el rendimiento individualizado de los estudiantes y de cada facultad y dárselo a conocer. El resumen del informe con la especificación de los puntos fuertes, de las áreas frontera y de aquellas áreas en las que se necesita mejorar en el conjunto de las ocho facultades y que constituye un libro blanco para la reforma de la educación médica en China, fue presentado al Ministro de Educación. El proceso de la evaluación "GMER" ha dejado también constituidos grupos de educadores médicos bien formados en cada institución, que podrán seguir evaluando a los estudiantes, usando instrumentos de calidad internacional. Como resultado de todo ello, se está produciendo una significativa aceleración de la reforma orientada a los resultados en un creciente número de facultades de medicina en China.
The most medical schools still continue the traditional "teacher-centered" curriculum, overcrowded with lecture hours and overemphasis on teaching and examinations, resulting in a passive students' learning attitude. However, in the past two decades, in the leading medical schools, many curriculum innovations were carried out. These schools have made efforts to incorporate into their curriculum integrated teaching principles, courses in humanities, ethics and society, informatics and computer sciences, knowledge of English. They also have focused on small group tutorials, problem solving skills, doctorpatient relationship and life-long learning attitudes. The present challenge for both, the government and the medical schools is an improvement of the quality of medical education to train qualified personnel who can adapt to rapidly changing medical practice and needs of Chinese people.

The Chinese Ministry of Education has been fully committed to use the best available expertise and international standards, from outside of the country, to enhance the academic and professional excellence of educational institutions. The best example of that was the invitation, of the Ministry of Education extended to the Institute for International Medical Education (IIME), to administer, in eight leading medical schools, assessment of graduates' competences envisaged in the Global Minimum Essential Requirements (GMER) document. The examination was followed by the process of defining international standards at the student-level and school-level. It has permitted to prepare the detailed reports on performances of individual students and each school and to hand them. The summary report on aggregated strengths, borderline areas and areas needing improvement of all eight schools together, which constitute a blueprint for medical education reform in China, was presented to the Minister of Education. The "GMER" evaluation process has left also a group of well-trained medical educators in each site who can continue to assess students by using internationalquality tools. As the result of all of that, a significant acceleration of outcome-oriented reforms, in increasing number of medical schools in China, has taking place. (End of an article) 